\title{
E-LEARNING IN THE HANDS OF GENERATION Y AND Z *
}

\author{
Kiril Postolov $^{1}$, Marija Magdinceva Sopova ${ }^{2}$ \& Aleksandra Janeska Iliev ${ }^{3}$
}

UDC /UDK: 37.018.43:004

JEL classification / JEL klasifikacija: D83, I2

DOI: https://doi.org/10.22598/pi-be/2017.11.2.107

Review / Pregledni rad

Received / Primljeno: September 28, 2017 / 28. rujna 2017.

Accepted for publishing / Prihvaćeno za tisak: November 27, 2017 / 27. studenoga 2017.

\section{Summary}

There have been a number of papers revolving around e-learning, since technological advancement has triggered interest and development for all online platforms. Still, the application of e-learning is not merely a technological solution, but a process involving many diverse factors such as social and behavioral contexts. The paper primarily focuses on the basic features of the most relevant generations currently representing the core workforce, Generation $Y$ and the upcoming Generation $Z$. This will form the basis for assumptions which will be tested with regard to the troubling labor market, at the same time connecting these generations with considerations about e-learning. Based on deductive reasoning, the focus is on the types of training, with a discussion of the main aspects and content of this type of learning. Despite the theoretical discussion, appropriate practical empirical research including the members of the mentioned generations and their applications of e-learning has been incorporated. Additionally, several relevant conclusions are made taking into account different variables related to e-learning based on a sample consisting of members of Generation $Y$ and Generation $Z$. The research will present certain indications related to generations $Y$ and $Z$, their orientation and willingness to use e-learning, primarily resulting from the characteristics and availability of the appropriate information technology. Although the research is rather new it should be noted that Generation $Z$ was born and raised with the web, they are digital-centric and technology is their blood.

\footnotetext{
The paper was presented at the 2nd International Conference "Business \& Entrepreneurial Economics -BEE2017” which was held in Brijuni from 24 to 26 May 2017 (www.bee-conference.com)

1 Kiril Postolov, Ph.D., Professor, Ss Cyril and Methodius University in Skopje, Faculty of Economics -Skopje, Republic of Macedonia, E-mail: kiril@eccf.ukim.edu.mk

2 Marija Magdinceva Sopova, Ph.D., Assistant Professor, University Goce Delcev, Stip, Faculty of Tourism and Business Logistics, Republic of Macedonia, E-mail:marija.magdinceva@ugd.edu.mk

3 Aleksandra Janeska Iliev, Ph.D., Assistant Professor, Ss Cyril and Methodius University in Skopje, Faculty of Economics -Skopje, Republic of Macedonia, E-mail: Aleksandra.Janeska-Iliev@eccf.ukim.edu.mk
} 
This paper should be given its practical and applied dimension by conducting relevant research. This analysis will offer insights into significant issues concerning e-learning and provide the foundations for further discussion on the trends related to the generation currently present as the dominant workforce and their attitude towards e-learning.

The limitations of the research are embedded in the struggle to measure some of the differences and characteristics within the different generational groups.

Key words: e-learning, Generation Y, Generation Z, characteristics, online learning, generational differences.

\section{INTRODUCTION}

Technological progress, particularly the Internet, has become one of the most important means providing learning resources for students to share and obtain information (Richard, Haya 2009). The intense changes in each and every segment have transformed life and the way people learn. Communication and the relationship between students and professors or lecturers has been evolving ever since. Some traditional aspects are still very present while others are diminishing. The physical form of classrooms has not transformed much since chalkboards were introduced in Prussian classrooms in the late 18th century (Konrad, 2007). However, fresh high-tech media offer extremely dynamic communications, while multimedia and computer networks make learning tools more suitable and easy to use. These possibilities have triggered a new era of learning where the individual approach is accessible to everyone. In the early sixties, there were predictions that in the coming years millions of students would have access to what Philip of Macedon's son Alexander enjoyed as a royal prerogative: the personal services of a tutor as well-informed and responsive as Aristotle. (Suppes, 1966, p. 201).

Additionally, information and databases have become more powerful, offering several channels, routes and resources enhancing and facilitating the process of education and thus re-defining the learning environment. The creation of this new learning environment has led to multidimensional learning and radically new ways and paths of learning. Research dealing with the process of learning and the use of technology for educational purposes has inspired numerous authors to discuss and develop relevant research in this field. It could be noted that academic research has considerably grown in respect to studies dealing with the use of technology in the process of education.

A different analysis has been evolving around the topic of so called electronic learning, also referred to as e-learning, indicating the exponential growth of its presence. In this respect, students nowadays are considered "digital natives" or users who have grown up using technologies such as computers, cell phones and the Internet (Prensky 2001). Hence the arrival of computers, tablets, and the Internet has led to the re-thinking of many traditional teaching practices and is generally seen as an opportunity for improvement (The Economist, 2013). Education, and even more so higher education teaching, needs to equip students with a wide range of skills needed in innovative and changing knowledge societies and economies. The education system must be 
capable of developing students who are able to be innovative in the workplace. Certain authors emphasize that technological competence also requires a transition from using the computer as an instructional delivery system to using the computer as a learning tool. (Lowther, et al. 998)

Although the Internet is considered a global technology, the efficiency of such tools should also be measured locally since users usually work in local/national contexts. The main objective of this study is to measure the influence of e-learning on students at one university, also taking into account certain factors influencing the students' positive opinion on the use of e-learning technology in teaching and learning. The successful implementation of e-learning tools depends on the perception of the users, as well as their knowledge and skills in using computers. There is a great number of studies that have shown that e-learning implementation is not simply a technological solution, but a process involving many different factors such as social and behavioral contexts.

Furthermore, there is a growing interest in the so called millennials, or Generation $\mathrm{Y}$, and the upcoming Generation $\mathrm{Z}$. Both have been growing up under the strong environmental impact of globalization and technical advancement. In that sense, their expectations with regard to the process of learning and education are dramatically different. Hence teachers should adapt to this rapidly changing environment where information and speed are crucial. Knowing and understanding these two generations which are potentially the main workforce is elementary for the future development of education.

\section{LITERATURE REVIEW}

Some discussions imply that the role of the teacher has changed since the development of the learner centered approach and that modern teaching involves more than classroom management, upfront explanations and testing. The teacher's job is to create a user friendly environment in which learning takes place. Modern literature proposes various aspects related to teaching, and the following are some of the innovative teaching methods used: e-learning, blended learning, case method, business game, role play simulation, project management simulation, virtonomics, Keller Plan, etc. Modern authors expand this list with different types of jigsaws, problem based learning and serious gaming etc. PBL (Problem Based Learning) in particular has gradually become an increasingly popular student centered approach in higher education teaching and learning across disciplines (Hoidn, Kärkkäinen, 2014).

Modern day learning environments are characterized by their place and time independence, their integrated presentation and communication facilities, and opportunities for the re-use of learning technologies as learning objects. Despite growing interest little is known about the important role of such factors in the adoption and use of technology in the context of developing countries such as Macedonia. In this context, some of the issues suggested by the Technology Acceptance Model (TAM), proposed by David, 1989, are often raised in academic research. The TAM model focuses on two theoretical constructs - perceived usefulness and perceived ease of use - which are the- 
orized to be fundamental determinants of system use. When considering a variety of variables that may influence the use of technological advancements, perceived usefulness is defined as "the degree to which a person believes that using a particular system would enhance his or her job performance, that is, that something is capable of being used advantageously. (David, 1989). On the other hand, perceived ease of use refers to "the degree to which a person believes that using a particular system would be free of effort”. (David, 1989). Some authors (Gefen, Straub, 1997) suggest that among the various theoretical models developed to examine users' intentions in using computer and communication technology, perceived usefulness is key in terms of influence on behavioral intentions. Technology offers tremendous opportunities for increasing the effectiveness and efficiency of education in the future. Students, faculty staff and administrators now use technology extensively in their daily activities and have become reasonably technologically knowledgeable. The trend of using e-learning as a learning and teaching tool is now rapidly expanding into education. Many researchers have used the TAM to measure students' acceptance of Web-based learning tools (Chang, Tung, 2008).

It is even more challenging to consider certain dimensions of the TAM with regard to discussions of the generational context. In this respect, starting from Generation $Y$, the focus is on technology and this is even more so in the case of the following Generation Z. Generation Y, or the so called millennials, and Generation Z are the most technologically savvy generational groups. This is even more pronounced in relation to learning or education in general. Therefore, it should be considered that technology has changed the way the members of these generations perceive and approach learning.

\subsection{Generation $Y$}

Generation Y thinks and learns differently from the preceding generations, due in particular to the rapidly changing, highly technological environment in which they have been raised. Generation Y, or millennials, refers to a generation born between the eighties and the start of the new millennium, who have a different set of personality characteristics, values, behaviors, expectations and perspectives. They are considered as the most educated, well-traveled and technologically sophisticated generation in general. This generation has not lived in a world without computers, the Internet, DVDs and cell phones. This group is considered to be more process and less outcome focused (Crampton et al., 2009). For Generation Y making a lot of money is less important; instead, their values are more oriented toward their contribution to society and their role as parents. Money does not necessarily motivate members of this generation, but the absence of money might lead them to lose motivation (Karp, 2002). Generation Y is similar to their Generation X counterparts in that Generation Y is independent, techno savvy, entrepreneurial, hardworking and thrives on flexibility (Tulgan, Martin, 2001). The first and main feature of the members of this generation is that they are individuals who have never lived in a world without technology. That means that mobile phones, the Internet, SMS, Skype, facebook, twitter, etc., are an integral part of their lives. It is a generation that doesn't know how to calculate by heart, but does so with the help of computers and mobile phones. Some authors (Siemens, 2004), believe that there are dramatic challeng- 
es related to knowledge and connects these to the rise of a number of major trends in learning, including (1) a change in the role of learning, from something people do less and less as they grow older to something that is, by necessity, continual and ongoing; (2) the simultaneous growth in the popularity and importance of informal learning; and (3) changes in the tools used to support learning in the form of new technologies which define and shape learners' thinking.

\subsection{Generation $\mathrm{Z}$}

Many demographers argue that all those born between 1978 and 2000 belong to the same generation, one gigantic "Millennial Generation." (Tulgan, 2013) However, this time frame is simply too broad and the historical events followed by technological advancement have led to distinct differences which need to be discussed separately.

Generation Z represents the greatest generational shift the workplace has ever seen. Generation $Z$ will present profound challenges to leaders, managers, supervisors, HR leaders, and educators in every sector of the workforce (Tulgan, 2013). Generation Z, who in most cases are the offspring of Generation X, were born after 1996, although different authors present some discrepancies with regard to the time frame. Some researchers provide the general definition that Generation Z was born in the 1990's and raised in the 2000s during the era of changes caused by the Internet, smart phones, laptops, freely available networks and digital media (Tulgan, 2013). In this context, Generation Z has been raised with social media, they are digital-centric and technology is their DNA. They are also referred to as Generation I, Gen Tech, Digital Natives, Gen Wii etc. (Singh, Dangmei, 2016). Members of Generation Z, also referred to as the N Generation (Net Generation), are resilient to major change, and the belief is that the cliché of a traditional, lecturing professor at the front of the room may not meet the end goal of education among the students. They were born and raised in the digital world and what distinguishes them from other generations is that their existence is more connected to electronics and the digital world. If Generation $Y$ was the most technologically advanced generation, the new generation, its successor, is naturally even more technologically dependent and up to date. In addition, this generation seeks choice and/or the perception of choice in all processes and desires structure and customization in all they do (Strauss, Howe, 2000). Generation X experienced a different family life, with high divorce rates, so that as parents they need to be independent because their family life was unpredictable. Thus they encourage independent thinking in their Generation $\mathrm{Z}$ offspring. (Tapscott, 2008). To the members of Gen $\mathrm{Z}$ or Gen N, the bringing up of facts is just data and not learning (Oblinger and Oblinger, 2005, p. 5.12). This generation, for better or for worse, does not respond well to the lecture and has become accustomed to interactivity. The traditional approach is becoming ineffective and they see those approaches as redundant.

\subsection{Conditions which lead to a change in learning methods}

In terms of discussing the essence of learning and training, we may note that on different occasions they have been treated as synonyms. There are, however, essen- 
tial and major differences which set them apart. Thus in order to clarify any potential misunderstandings, certain aspects of the literature should be reviewed in terms of how they are understood. A study of the past indicates that people have always wanted to make their life as easy as possible and carry out their activities more efficiently. Most frequently people researched learning and training by including numerous attempts and learning errors. It was a time when learning and training was based upon empirical research, practical experience and work practice. One of the major phases in applying different methods of learning and training began during World War II. Remarkably, the reason for this was linked to the fact that using conventional methods was not showing itself to be a huge success in the circumstances of the time and there was, therefore, a need for change. This was the main reason why military strategists and their leaders recruited scientists from different disciplines to assist in military operations. With the help of scientific research, rational, systematic, scientifically grounded strategies and techniques, and other analytical methods (such as mathematical modeling) were applied in the process of learning and training to improve decision making in a rational and useful manner.

However, the progress of sophisticated technology, along with declining costs, has changed the way learning and training are performed nowadays, making them more truthful, more fun, unusual and often allowing participants to decide when and where to make use of them. The introduction of the Internet, CDs, DVDs, computers, cable TV, 4G mobile technology, mobile phones etc. have dramatically changed the way of life and, in that sense, have transformed the way of learning in general. Nowadays, learning and training almost cannot do without some of these tools. Technology offers a number of obvious advantages, including reducing travel costs, greater availability of learning and training, consistency in delivery, availability of experts, easier sharing of materials for training purposes, the possibility of creating learning platforms etc. The following can be highlighted as part of the actual benefits of using technology in learning and training (Noe, 2010, p.297):

- Gaining control over the time and place of training;

- Ease of access to data, resources, experts etc.;

- Using a simulated virtual reality environment which may appear similar to reality;

- Selecting the best suited media type (printed materials, audio, video or a combination etc.);

- Registration for training, testing, record keeping can be made electronically, eliminating the need for paper records;

- Achievements of students during training can be monitored;

- Classical training by teachers can be made available to employees without the need for them to come to head offices etc. 


\subsection{Methods of learning}

The literature distinguishes between various types of learning methods from different viewpoints. Some authors propose the following: methods of presentation, case study and e-learning (Raymond, 2010). The first thing that needs to be put into perspective is related to what the role of the lecturer or teacher actually is in the context of being the driving force towards innovative teaching techniques. In the traditional sense, direct lecturing being provided by the teacher is considered to be one of the essential and practically irreplaceable elements in the process of learning and education. This arises from the fact that the actual live lectures of the teacher cannot be replaced by any other technique and therefore they have been present for centuries in all stages of education. It has often been stated that it is teachers and lecturers that should provide guidance and directions in the process of learning.

The presence of new technologies takes primacy over tradition, but the greatest results are thought to come from combining e-learning and traditional approaches - so called blended learning. Unlike traditional methods, these methods have higher quality, greater possibilities for individual training, and knowledge can be acquired by simply searching on the Internet. On the other hand, these methods are more expensive than the traditional methods of training and also require technical knowledge and proficiency in foreign languages. E-learning can be implemented in a variety of ways, such as through the use of self-paced independent study units, asynchronous interactive sessions (where participants interact at different times) or synchronous interactive settings (where learners meet in real time) (Ryan, 2001). Some authors propose other methods of learning (Horton, 2012), such as: individual courses, gaming and simulations, mobile learning, social/peer to peer learning and virtual classrooms.

\subsection{Training and e-learning}

The literature proposes many different definitions related to training and some of them are included in the analysis. The diversity of their content is determined by the authors' approach. Thus, according to some authors, training is defined as a process in which people acquire skills in order to successfully perform tasks (Mathis, Jackson, 2008). Training should provide employees with the appropriate knowledge and skills that they can use at their current jobs. Another approach states that training can be defined as an effort to improve the performance of employees at their workplace or a related post. It is considered an activity that makes changes to specific knowledge, abilities, skills, attitudes and behavior (Petkovic et al., 2003). Further, training can be defined as the systematic process of enriching and expanding the knowledge, skills and attitudes of people to provide better and more efficient performance at work or at a specific workplace (Bojadzhioski, Evtimov, 2009). Of course, there are countless different approaches and definitions of what constitutes training (if you type training on google.com, 577 million pages about what constitutes training will open in 0.53 seconds).

The literature deals with various groupings of training methods from different viewpoints. For the purposes of this paper, we have used the classification by Raymond 
(Raymond, 2010), according to whom there are: methods of presentation, hands-on methods and group methods, as well as methods linked to e-learning and mobile technology. E-learning is a concept that covers a variety of applications, processes and learning methods. Furthermore, learning systems based on formalized teaching but with the help of electronic resources are known as e-learning. Different approaches can also be found in the literature with regard to definitions of e-learning. Some authors suggest (Raymond, 2010) that e-learning is defined as one of the methods of training. Other discussions have considered e-learning as "the use of the Internet or organizational intranet to conduct training" (Mathis, Jackson, p. 279). Further, it is suggested that e-learning "covers the use of electronic technologies in creating a learning experience" (Horton, 2012, p.1). Another definition proposes that this is the process of the transfer of a learning, training or educational program by electronic means. Undoubtedly, e-learning involves the use of a computer or electronic device (e.g. a mobile phone) in some way to provide training, educational or learning materials. (Stockley, 2003). Whereas teaching can be based in or out of the classroom, it is the use of computers and the Internet that comprises the major component of e-learning. E-learning can also be labeled as the network enabled transfer of skills and knowledge, where the delivery of education is made to a number of recipients at the same or different times. Clearly, almost all definitions of e-learning focus on the use of electronic resources, computers and the Internet in the process of teaching.

\subsection{E-learning}

Some authors argue (Govindasamy, 2002) that e-learning has offered another avenue to enhance teaching and learning. Generally speaking, it includes all types of teaching methods via electronic media, such as: the Internet, intranet, extranet, satellite broadcasts, audio/video, interactive TV and CD-ROMs. The true significance of e-learning lies in its availability, offering training anytime and anywhere to anyone, as well as offering this training to the right person with competent technical ability or knowledge at the right time. Some studies (Thornton, et al., 2004) suggest that e-learning is a tool which can improve teaching and learning skills, while its effectiveness depends on whether the tool is used properly. E-learning makes new knowledge and skills available instantly and reduces the learning time required to master even the most complicated topics. Modern technologies, particularly the Internet, have made education no longer limited to the four walls of the classroom. The trend of using e-learning as a learning and/or teaching tool is now rapidly expanding into education (Shu-Sheng Liaw, et al., 2007). Through the innovative use of modern technology, e-learning not only revolutionizes education and makes it more accessible, it also entails formidable challenges for instructors and learners. E-learning environments increasingly serve as important infrastructural features of universities that enable teachers to provide students with different representations of knowledge and to enhance interaction between teachers and students, as well as among the students themselves (Mahdizadeh et al., 2007). 


\section{ANALITICAL FRAMEWORK}

\subsection{Methodology}

Linear Multiple Regression analysis is used to examine some of the relationships related to aspects of learning, based on respondents mainly on the borderline between Generation Y and Generation Z. The independent variables include different aspects which could be connected to perceived usefulness and perceived ease of use. As the research has been revolving around e-learning, the dependent variable was set to be e-learning. The independent variables were grouped into three blocks, adding variables which could potentially influence the dependent variable. The variable related to the age of the respondents is present in all three blocks and is considered a control variable.

The first block is mainly related to aspects of training, hence the following variables were included: the frequency of using training, the usefulness related to training in general, the importance of training and technological advancement influencing the choice of training, and the control variable related to the age of the respondents.

The second block is related to aspects of e-learning so the following variables were added in this block: e-learning, e-learning usefulness, willingness to pay to use e-learning platforms.

The third block relates mainly to the perceived ease of use, hence the variables added are: the knowledge and experience necessary to apply e-learning, use of email.

\subsection{Sample}

The questionnaire was distributed among the population of students in undergraduate and postgraduate studies in the period of January until March 2017. The population consisted of students at the Ss. Cyril and Methodius University in Skopje, Faculty of Economics. The total number of replies was 43 , with the respondents predominantly, or $72.1 \%$, females. The respondents mostly come from Skopje, the capital of Macedonia, with over $60 \%$ and more than $50 \%$ have some previous work experience.

\subsection{Questionnaire}

The questionnaire consisted of 16 questions, including demographic aspects, as well as questions related to the main constructs - the perceived usefulness and perceived ease of use, considering relevant authors such as Davis, 1989 with regard to the TAM model.

\subsection{Results}

The descriptive data provided from the sample indicates that most of the respondents are 21 years old, meaning that they were born in 1996. Therefore, depending on the authors consulted, they could be considered on the border between Generation Y and Generation Z. More than $70 \%$ of the respondents have at least taken part in training, and more than $80 \%$ consider training important. Around $84 \%$ of the respondents consider that technological 
advancement influences the preferred choice of training. It is interesting that around $50 \%$ only partially agree that e-learning gives a higher quality to the process of learning, whereas $47 \%$ consider that e-learning enables the development of skills and appropriate knowledge. Around 30\% consider that using e-platforms is useful since they are willing to pay for this and they believe that eventually they will make use of them in their future professional development. Over $60 \%$ suggest that they do not possess the sufficient knowledge to use appropriate e-learning platforms, whereas only $5 \%$ do not use e-mail at all.

Table 1: Multiple regression analysis

\begin{tabular}{|c|c|c|c|c|c|c|}
\hline \multirow{2}{*}{ VARIABLE } & \multicolumn{2}{|c|}{ Block 1} & \multicolumn{2}{|c|}{ Block 2} & \multicolumn{2}{|c|}{ Block 3} \\
\hline & B & Sig. & B & B & Sig. & B \\
\hline \multicolumn{7}{|l|}{ STEP 1} \\
\hline training & .489 & $.058^{*}$ & .516 & $.052^{*}$ & .331 & .228 \\
\hline importance of training & $(.272)$ & .561 & $(.459)$ & .385 & $(.316)$ & .548 \\
\hline training influencing career & $(.185)$ & .718 & .085 & .885 & .060 & .917 \\
\hline $\begin{array}{l}\text { technological advancement influencing the use } \\
\text { of training }\end{array}$ & .742 & $.021^{*}$ & .614 & .073 & .449 & .186 \\
\hline age & .109 & .516 & .131 & .459 & .151 & .383 \\
\hline \multicolumn{7}{|l|}{ STEP 2} \\
\hline e-learning is better & & & .330 & .308 & .393 & .216 \\
\hline $\begin{array}{l}\text { willing and prepared to pay in the future for } \\
\text { using e-platforms }\end{array}$ & & & $(.401)$ & .233 & $(.588)$ & .090 \\
\hline e-learning usefulness & & & .079 & .819 & .063 & .851 \\
\hline \multicolumn{7}{|l|}{ STEP 3} \\
\hline lack of knowledge & & & & & $(.147)$ & .331 \\
\hline use email & & & & & .273 & .144 \\
\hline $\mathrm{R}^{2}$ & \multicolumn{2}{|c|}{253} & \multicolumn{2}{|c|}{,289 } & \multicolumn{2}{|c|}{, 369} \\
\hline F-statistics block & \multicolumn{2}{|c|}{2.511} & \multicolumn{2}{|c|}{1.730} & \multicolumn{2}{|c|}{1.870} \\
\hline change in $\mathrm{R}^{2}$ & \multicolumn{2}{|c|}{.253} & \multicolumn{2}{|c|}{.036} & \multicolumn{2}{|c|}{.080} \\
\hline F change & \multicolumn{2}{|c|}{2.511} & \multicolumn{2}{|c|}{.574} & \multicolumn{2}{|c|}{2.016} \\
\hline
\end{tabular}

Source: Proposed by the authors

Further, the data was set in SPSS and a multiple regression analysis was performed. The results provided from the three blocks indicate that the first and the third add significance to the model. This means that, in general, in respect of certain aspects related to e-learning, there is no indication in this research of any significant impact on them i.e on the process of e-learning, mainly the perceived usefulness of e-learning. At the same time, we used age as a control variable within the three blocks and, in this sense, age has not displayed any significant influence on the dependent variable. This could be rooted in the size of the sample, as well as in the lack of any higher generational gap among the respondents. On the other hand, significant impact could be inferred from this analysis for the dependent variable e-learning with regard to some aspects of the ease of use of e-learning. Nevertheless, in the model as a whole, e-learning is most significantly influenced by the attitude towards training in general. Respondents who use training more often tend to use e-learning more, which is logical keeping in mind the current trends in using technology. 
In line with this, growing technological advancement is thought to influence the use of training and is also linked positively to e-learning. It could also be noted that the perceived ease of use is indicated as a significant influence with regard to e-learning.

\section{CONCLUSION}

The debates on e-learning have been gaining importance worldwide, therefore an analysis of this topic in developing countries cannot and should not be omitted. Although research and data is limited, there are still many indications and a lot of information related to aspects of e-learning which can be used. Referring to different modes of learning, especially with regard to e-learning, it could be stated that it is strongly related to technological advancement, in particular the boom of the Internet. E-learning is an extremely flexible approach strongly related to technology that can be used to cover diverse learning modes from self-paced to interactive or live learning which can match the varied teaching and learning needs. The introduction of e-learning makes new knowledge and skills available instantly and reduces the learning time required to master even the most complex topics. The discussion around e-learning is evolving, becoming a major trend in education. Technologies, predominantly the Internet, have made education no longer limited to the four walls of the classroom.

Among the new generations $\mathrm{Y}$ and $\mathrm{Z}$, which have not known a world without technology, e-learning is naturally accepted and expected. These generations are technologically well educated and have certain expectations related to the use and implementation of the different opportunities offered by technology.

The research conducted as part of this paper has offered some insights related to the attitudes and behaviors of the members of Generation $\mathrm{Y}$ and $\mathrm{Z}$ in respect of e-learning. The results indicated that most of the respondents consider the importance of e- learning in the light of developing further skills. An interesting outcome is that an overriding percentage of respondents believe they do not have sufficient knowledge and experience to take advantage of e-learning properly. In terms of the empirical analysis, the dependent variable represented by e-learning was considered to be significantly influenced by training. Hence individuals who have implied more interest in training in general accordingly favor e-learning more as well. Technological advancement has also shown to be significant in terms of the influence of aspects of e-learning; the development of new technology increases the interest in and involvement with e-learning. On the other hand, the age aspects linked to the generational aspects have not shown themselves to have significant influence on e-learning in our research. This could be rooted in the limitations of this research, i.e. the limited size of the sample, as well as the lack of diversity with regard to the age groups included. Still, it could be considered that the new and fresh generations have made technological innovations, tools and applications an integral part of their life. They have indicated a strong willingness and acceptance towards all the potential benefits offered by technology. Therefore, for these generations e-learning presents an expected tool in their further professional development and education. Research should be extended further to include a larger pool of generations so that a distinction can be made in respect of the acceptance and use of e-learning as a tool for gaining additional knowledge. 


\section{REFERENCES:}

1. Barrows, H.S. (2002), "Is it truly possible to have such a thing as dPBL?" Distance Education, Vol. 23/1, pp. 119-122.

2. Bojadzioski, D., Eftimov, L. (2009) Mendzment na covecki resurski, Ekonomski fakultet-Skopje, Skopje.

3. Chang , S. C., Tung, F. C. (2008), "An empirical investigation of students' behavioural intentions to use the online learning course websites," British Journal of Educational Technology, vol. 39, no. 1 pp. 71-83

4. Crampton, S., Hodge,J.H (2009), “Generation Y:Unchartered Territory,” Journal of Business \& Economics Research, Vol. 7, No.4, pp. 1-6.

5. Davis, F.D., (1989), "Perceived usefulness, perceived ease of use, and user acceptance of information technology", MIS quarterly, pp.319-340.

6. Fry, H., (2003), Marshall, Stephanie 'Understanding Student Learning' in Heather Fry, Steve Ketteridge and Stephanie Marshall (eds.) A Handbook for Teaching and Learning in Higher Education., Kogan Page

7. Govindasamy, T. (2002), "Successful implementation of E-learning pedagogical considerations', Internet and Higher Education, Vol.4, pp.287-299.

8. Hoidn, S.,Kärkkäinen, K., (2014), "Promoting skills for innovation in higher education: A literature review on the effectiveness of problem-based learning and of teaching behaviours". OECD Education Working Papers, (100), p.0_1.

9. Horton, W. (2012), E-Learning by Design, Pfeiffer, San Francisco.

10. Howe, N., Strauss, W. (2000). Millennials Rising: The Next Great Generation. Vintage Books New York.

11. Karp, H. (2002), Bridging the boomer - Xer gap: Creating authentic teams for high performance at work, Davies-Black Publishing.

12. Lawson, K. (2006) Improving On-The-Job Training and Coaching, ASTD.

13. Li, N., Kirkup, G. (2007), "Gender and cultural differences in Internet use: A study of China and the UK," Computers \& Education, vol. 48, no. 2, pp. 301-317

14. Liu, S. H., Liao, H. L., Peng, C. J. (2005), "Applying the technology acceptance model and flow theory to online e-Learning users'acceptance behavior," E-learning, vol. 4, no. H6, pp. H8.

15. Mathis, R.L., Jackson, J.H. (2008) Human resource management, $12^{\text {th }}$ edition, Thomson South- Western, Mason.

16. Oblinger, D. , Oblinger, J., (2005)," Is it age or IT: First steps toward understanding the net generation', Educating the net generation, Vol.2, No.1-2, p.20.

17. Park, J. (2007), "Factors associated with transfer of training in Workplace E-Learning”, Journal of Workplace Learning, No. 19, p. 311 
18. Petkovic, M., Janikievic, N., Bogicevic, B (2003) Organizacija, teorija, dizajn, ponasanje, promene, drugo izdanje, Ekonomski fakultet, Beograd.

19. Prensky, M. (2001),"Digital natives, digital immigrants", On the horizon, Vol. 9,No.5, pp.1-6.

20. Raju, D.T.,(2004), Innovative teaching methods. Orientation Programme, p.89.

21. Raymond, N. 2010) Employee Training and Development, $5^{\text {th }}$ Revised edition, McGraw-Hill Education, Boston.

22. Richard, H., Haya, A. (2009),"Examining student decision to adopt web 2.0 technologies: theory and empirical tests", Journal of computing in higher education, Vol.21, No.3, pp.183-198.

23. Ryan, S. (2001), “Is online learning right for you?” American Agent \& Broker, Vol.73, No.6, pp.54-58.

24. Schwartz, D.L., R. Lindgren and S. Lewis (2009), "Constructivism in an age of non-constructivist assessments" in S. Tobias and T.M. Duffy (eds.), Constructivist Instruction: Success or Failure?, Routledge, New York, pp. 34-61.

25. Siemens, G. (2004), 'Connectivism: A Learning Theory for The Digital Age', International Journal of Instructional Technology \& Distance Learning, vol. 2 no.1

26. Singh, A.P. and Dangmei, J.,(2016), "Understanding the generation $\mathrm{z}$ : the future workforce", South-Asian Journal of Multidisciplinary Studies Vol. 3 Issue 3

27. Suppes, P. (1966). “The uses of computers in education", Scientific American, Vol.215,pp. 206-220.

28. Tapscott, D.(2008), Grown Up Digital: How the Net Generation Is Changing Your World. McGraw-Hill. pp. 15-16.

29. Thornton,M., Jefferies, A., Jones,I.,Alltree,J., Leinonen E.(2004), “Changing pedagogy: does the introduction of networked learning have an impact on teaching?", Networked Learning Conference Symposium 8, April 5-7, Lancaster University, UK.

30. Tulgan, B. (1996), Managing Generation X: How to Bring out the Best in young Talent, Capstone, Oxford.

31. Tulgan, B., (2013), Meet Generation Z: The second generation within the giant" Millennial” cohort Rainmaker Thinking.

32. Tulgan, B., (2016), “ Bridging the Soft-Skills Gap”, Employment Relations Today, Vol. 42,No.4, pp.25-33

33. Tulgan, B., Martin, C. A. (2001), "Managing Generation Y”, Business Week Online.

34. Venkatesh, V., Bala, H. (2008), "Technology acceptance model 3 and a research agenda on interventions," Decision Sciences, , vol. 39, no. 2, pp. 273-315.

35. Zhang, S., Zhao, J., Tan, W. (2008), "Extending TAM for online learning systems: An intrinsic motivation perspective," Tsinghua Science \& Technology, vol. 13, no. 3 pp. 312-317. 


\title{
E-UČENJE U RUKAMA GENERACIJE Y I Z*
}

\author{
Kiril Postolov ${ }^{4}$, Marija Magdinceva Sopova ${ }^{5}$ \& Aleksandra Janeska Iliev ${ }^{6}$
}

\section{Sažetak}

Otkada je tehnološki napredak potaknuo zanimanje za sve online platforme kao $i$ njihov razvoj pojavio se veći broj radova usredotočenih na e-učenje. Ipak, primjena e-učenja ne predstavlja samo tehnološko rješenje, već je riječ o procesu koji obuhvaća brojne $i$ raznovrsne čimbenike kao što su društveni čimbenici i oni povezani s ponašanjem. Ovaj se rad prvenstveno bavi temeljnim odlikama najrelevantnijih generacija koje trenutno predstavljaju radnu snagu - generacijom $Y$ i nadolazećom generacijom $Z$. To je temelj $z a$ pretpostavke koje će se ispitati s obzirom na problematično tržište rada, istovremeno povezujući te generacije s razmatranjima o e-učenju. Uz pomoć deduktivnog rasuđivanja, $u$ središtu zanimanja su vrste obučavanja uz raspravu o glavnim aspektima i sadržaju ove vrste učenja. Pored toga, iznijet će se nekoliko relevantnih zaključaka sobzirom na različite varijable povezane s e-učenjem na temelju uzorka koji se sastoji od pripadnika generacija $Y i Z$. Istraživanje će iznijeti određene pokazatelje povezane s generacijama $Y i$ $Z$, njihovom orijentacijom i spremnošću da koriste e-učenje, a koji su prvenstveno rezultat odlika i dostupnosti prikladne informacijske tehnologije. Iako je istraživanje prilično novo, treba napomenuti da je generacija $Z$ rođena i odrasla uz internet, da su usmjereni na digitalno, a tehnologija im je u krvi. Ovaj bi rad trebao dobiti praktičnu i primijenjenu dimenziju provođenjem relevantnih istraživanja. Ova će analiza ponuditi uvid u važna pitanja u pogledu e-učenja te pružiti temelj za daljnje rasprave o trendovima povezanima s generacijom koja trenutno čini dominantni dio radne snage te o stavovima pripadnika te generacije u pogledu e-učenja. Ograničenja istraživanja izviru iz poteškoća u mjerenju određenih razlika i odlika različitih generacijskih skupina.

Ključne riječi: e-učenje, generacija y, generacija $z$, odlike, mrežno učenje, generacijske razlike.

JEL klasifikacija: D83, I2

\footnotetext{
Rad je prezentiran na 2. Međunarodnoj konferenciji "Business \& Entrepreneurial Economics-BEE2017" koja je održana na Brijunima od 24. do 26. svibnja 2017. godine (www.bee-conference.com)

4 Dr. sc. Kiril Postolov, profesor, Sveučilište Svetih Ćirila i Metoda u Skopju, Ekonomski fakultet, Republika Makedonija, E-mail: kiril@eccf.ukim.edu.mk

5 Dr. sc. Marija Magdinceva Sopova, docent, Fakultet turizma i poslovne logistike, Sveučilište Goce Delčev, Štip, Republika Makedonija, E-mail:marija.magdinceva@ugd.edu.mk

6 Dr. sc. Aleksandra Janeska Iliev, docent, Sveučilište Svetih Ćirila i Metoda u Skopju, Ekonomski fakultet, Republika Makedonija, E-mail: Aleksandra.Janeska-Iliev@eccf.ukim.edu.mk
} 